\title{
URGENSI PENGAWASAN KEAMANAN PANGAN BERBASIS SISTEM MANAJEMEN RISIKO BAGI PERLINDUNGAN KONSUMEN
}

\author{
Ahmad Zazili ${ }^{1}$ \\ Fakultas Hukum Universitas Lampung \\ zazy_01@yahoo.co.id
}

\begin{abstract}
The main issues of food safety is around the safety and quality. Many food products on the market unsafe to consumption because have microbial contamination, chemical contamination, and contain hazardous chemicals such as formaldehyde, borax, rhodamine $B$, methyl yellow. To protect of consumers need supervision to food producers by the risk management system. Supervision of food product security is mandated by Bill Of The Republic Of Indonesia Number 8 Year 1999 Concerning Consumer Protection, and Bill Of The Republic Of Indonesia Number 18 Year 2012 Concerning Food
\end{abstract}

Keywords: Supervision of Food Safety, Management Risk System, Consumer Protection.

Abstrak

Permasalahan utama keamanan produk pangan adalah belum terjaminnya keamanan, mutu dan kualitas. Banyak produk pangan yang beredar di pasaran tidak aman dikonsumsi karena tercemar mikroba, cemaran kimiawi, serta mengandung bahan kimia berbahaya seperti formalin, boraks, rhodamin B, metil yellow. Untuk melindungi kepentingan konsumen maka diperlukan pengawasan terhadap pelaku usaha pangan. Bentuk pengawasan yang dapat dilakukan adalah pengawasan berbasis sistem manajemen risiko. Pengawasan terhadap keamanan produk pangan merupakan amanah Undang-Undang Nomor 8 Tahun 1999 Tentang Perlindungan Konsumen, dan Undang-Undang Nomor 18 Tahun 2012 Tentang Pangan.

Kata kunci: Pengawasan Keamanan Pangan, Sistem Manajemen Risiko, Perlindungan Konsumen.

\section{PENDAHULUAN}

Salah satu bidang pembangunan yang berkaitan erat dengan kesejahteraan dan kemakmuran masyarakat adalah pemenuhan kebutuhan dasar berupa kecukupan pangan. Pangan harus senantiasa tersedia secara cukup, aman, bermutu, bergizi, dan beragam dengan harga yang terjangkau oleh daya beli masyarakat, serta tidak bertentangan dengan agama, keyakinan, dan budaya masyarakat.

1 Dosen Fakultas Hukum Universitas Lampung, jalan. Soemantri Brodjonegoro No. 1 Bandar Lampung), Penulis adalah Awardee Beasiswa BUDI DN-LPDP pada Program Doktor Ilmu Hukum Universitas Brawijaya 2016Sekarang)

Ahmad Zazili, Urgensi Pengawasan Keamanan Pangan Berbasis Sistem Manajemen Risiko Bagi Perlindungan Konsumen 
Pentingnya pangan karena merupakan kebutuhan dasar manusia yang paling utama berkaitan dengan kelangsungan hidup dan merupakan bagian hak asasi manusia.

Menurut Suratmono, Direktur Inspeksi dan Sertifikasi Pangan, Badan Pengawas Obat dan Makanan (BPOM) pada tanggal 16 Juli 2012 saat acara media gathering bertema 'Pengawasan Keamanan Pangan', permasalahan utama menyangkut keamanan produk pangan di negaranegara berkembang termasuk di Indonesia adalah belum terjaminnya keamanan, mutu dan kualitas. Produk pangan yang beredar di pasaran masih banyak ditemukan tidak aman dikonsumsi karena tercemar mikroba, cemaran kimiawi, serta mengandung bahan kimia berbahaya Seperti formalin, boraks, rhodamin $B$, metil yellow dan lain-lain serta penggunaan bahan tambahan pangan berlebih. ${ }^{2}$

Hasil pengawasan keamanan dan mutu produk pangan yang dilakukan Badan Pengawas Obat dan Makanan ( BPOM) selama tahun 2015 ditemukan produk pangan yang mengandung bahan berbahaya yang disalahgunakan sebagai Bahan Tambahan Pangan, yaitu sebanyak 162 sampel mengandung Boraks; 110 sampel mengandung Rhodamin B; 228 sampel mengandung Formalin dan 4 sampel mengandung Methanyl Yellow. ${ }^{3}$ Secara lengkap disajikan dalam tabel berikut ini.

Tabel 1

Hasil Pengujian Bahan Tambahan yang Dilarang

Digunakan Pada Pangan Tahun 2015

\begin{tabular}{|l|l|c|l|}
\hline $\begin{array}{c}\text { Bahan } \\
\text { Tambahan } \\
\text { yang } \\
\text { Dilarang }\end{array}$ & $\begin{array}{c}\text { Jumlah } \\
\text { Sampel }\end{array}$ & $\begin{array}{c}\text { Tidak } \\
\text { memenuhi } \\
\text { syarat } \\
\text { sampel) }\end{array}$ & $\begin{array}{r}\text { Jenis pangan tidak } \\
\text { memenuhi syarat }\end{array}$ \\
\hline Formalin & 3.776 & $227(6,01 \%)$ & $\begin{array}{l}\text { Bakso Kepiting, Cincau, Ikan, } \\
\text { Cumi Asin, Mie, Kolang Kaling, } \\
\text { Tahu, Teri, Ayam, Sosis, Siomay }\end{array}$ \\
\hline Boraks & 4.635 & $170(3,67 \%)$ & $\begin{array}{l}\text { Cincau, Candil Merah, Rumput } \\
\text { laut, Dawet, Bakwan, Bakso, } \\
\text { Batagor, Siiomay, Kerupuk, } \\
\text { Rengginang, Lontong, Empek- } \\
\text { empek, Mie, } \\
\text { Arem-arem, Otak-otak, Tahu }\end{array}$ \\
\hline Rhodamin B & 3.077 & $334(10,85 \%)$ & $\begin{array}{l}\text { Kerupuk, Agar-agar, Es Delima, } \\
\text { Es Cendol, Es Sirup Merah, Kue }\end{array}$ \\
\hline
\end{tabular}

2 Kompas.com, Teliti 7 Hal Ini Saat Baca Label Makanan, diakses tanggal 16 maret 2017 dari ", https://lifestyle.kompas.com/read/2012/07/17/0718222/Teliti\%20Ini.Saat. Baca.Label.Makanan. ,

${ }^{3}$ Laporan Tahun 2015 Badan Pengawasan Obat dan Makanan RI, Hasil Uji Laboratorium 


\begin{tabular}{|l|l|l|l|}
\hline & & & $\begin{array}{l}\text { Ku, Kue Lapis, Kue Mutiara, } \\
\text { Pacar Cina, Terasi, Dodol, Wajik, } \\
\text { Bolu Merah, Ampyang, Gulali, } \\
\text { Putu Mayang }\end{array}$ \\
\hline Metil Yelow & 1.850 & $6(0,32 \%)$ & Cendol, Pacar Cina, Srundeng \\
\hline
\end{tabular}

(Sumber: Laporan Tahunan BPOM tahun 2015)

Berdasarkan data di atas dapat dikemukakan bahwa banyak produk pangan yang beredar di pasaran tidak aman untuk dikonsumsi . Dalam upaya untuk menghindarkan konsumen dari ancaman produk pangan yang tidak aman dikonsumsi maka perlu dilakukan pengawasan terhadap produk pangan baik pada tahap produksi maupun pada tahap pasca produksi atau tahap peredaran produk pangan. Sistem pengawasan keamanan pangan yang digunakan oleh pemerintah selama ini adalah pengawasan "full spectrum" yaitu berupa pengawasan "pre market" dan pengawasan "post market".

Pengawasan produk sebelum beredar bertujuan untuk menjamin produk obat dan makanan terjamin aman, bermanfaat dan bermutu sebelum diedarkan. Selanjutnya setelah produk obat dan makanan beredar BPOM melakukan pengawasan dengan melakukan sampling terhadap produk obat dan makanan yang beredar dan dilakukan uji laboratorium untuk memastikan apakah produk masih aman, bermanfaat dan bermutu. ${ }^{4}$

Sistem ini memiliki kelemahan, yaitu tidak semua produk pangan dan pelaku usaha dapat diawasi karena banyaknya jumlah produk pangan dan pelaku usaha yang memproduksi pangan. Tulisan ini membahas dua hal yaitu pertama, urgensi pengawasan keamanan produk pangan; dan kedua, sistem pengawasan keamanan pangan yang berbasis sistem manajemen risiko untuk mewujudkan perlindungan konsumen.

\section{PEMBAHASAN}

\section{Urgensi Pengawasan Keamanan Pangan sebagai Wujud Perlindungan Konsumen}

Manusia merupakan makhluk ciptaan Tuhan yang sejak lahir memiliki hak-hak dasar yaitu hak untuk hidup, hak untuk dilindungi, hak untuk bebas dan hak-hak lainnya. Pada dasarnya setiap manusia

${ }^{4}$ Badan Pengawasan Obat dan Makanan RI, Laporan Kinerja 2016, Direktorat Pengawasan Produk dan Bahan Berbahaya, diakses tanggal 2 Januari 2019

dari

https://www.pom.go.id/new/admin/dat/20180710/22.\%20Lapkin\%20Dit\%20 Was\%20PBB\%20Tahun\%202016.pdf 
memiliki hak untuk dilindungi termasuk dalam kehidupan bernegara. Setiap warganegara akan mendapat perlindungan dari negara, oleh karena itu hukum yang dibuat negara harus melindungi hak-hak dasar tersebut. Dengan adanya hak asasi tersebut, manusia dapat mengembangkan diri pribadi, peranan, dan sumbangannya bagi kesejahteraan hidup manusia. ${ }^{5}$

Menurut Janus Sidabalok 6 ada empat alasan pokok mengapa konsumen perlu dilindungi, yaitu sebagai berikut : melindungi konsumen sama artinya dengan melindungi seluruh bangsa sebagaimana diamanatkan oleh tujuan pembangunan nasional menurut UUD NRI 1945; melindungi konsumen perlu untuk menghindarkan konsumen dari dampak negatif penggunaan teknologi; melindungi konsumen perlu untuk melahirkan manusia-manusia yang sehat rohani dan jasmani sebagai pelaku-pelaku pembangunan, yang berarti juga untuk menjaga kesinambungan pembangunan nasional; melindungi konsumen perlu untuk menjamin sumber dana pembangunan yang bersumber dari masyarakat konsumen.

Berkenaan dengan perlindungan konsumen Setiawan menyatakan bahwa perlindungan konsumen mempunyai dua aspek yang bermuara pada praktik perdagangan yang tidak jujur (unfair trade practices) dan masalah keterikatan pada syarat-syarat umum dalam suatu perjanjian. Dalam pandangan ini secara tegas dinyatakan bahwa upaya untuk melakukan perlindungan terhadap konsumen disebabkan adanya tindakan-tindakan atau perbuatan para pelaku usaha dalam menjalankan aktifitas bisnisnya yang tidak jujur sehingga dapat merugikan konsumen. ${ }^{7}$ Adijaya Yusuf dan John W. Head ${ }^{8}$, mengatakan bahwa perlindungan konsumen adalah istilah yang digunakan untuk menggambarkan perlindungan hukum yang diberikan kepada konsumen dalam usahanya untuk memenuhi kebutuhannya dari hal-hal yang dapat merugikan konsumen.

Menurut Ali Mansyur kepentingan konsumen dapat dibagi menjadi empat macam kepentingan, yaitu sebagai berikut ${ }^{9}$ : Kepentingan fisik berkenaan dengan badan atau tubuh yang berkaitan dengan keamanan dan keselamatan tubuh dan jiwa dalam penggunaan barang dan/atau jasa. Kepentingan fisik ini juga berkaitan dengan kesehatan

5 Bernald L.Tanya, Yoan N. Simanjuntak, Markus Y.Hage, Teori Hukum Strategi Tertib Hukum Manusia Lintas Ruang dan Generasi, Yogyakarta: Genta Publishing, 2010, hlm. 72-73

6 Janus Sidabalok, Hukum Perlindungan Konsumen di Indonesia, Bandung: PT. Citra Aditya Bakti, 2006, hlm, . 6

7 Setiawan, Makalah Produsen atau Konsumen; Siapa Dilindungi Hukum, Jakarta, 2001, hlm. 152

8 Ibid

9 M Ali Mansyur, Penegakan Hukum Tentang Tanggung Gugat Produsen Dalam Perwujudan Perlindungan Konsumen, Yogyakarta: Penerbit GentaPress, 2007, hlm. 81 
dan keselamtan jiwa. Kepentingan fisik konsumen ini harus diperhatikan oleh pelaku usaha. Kepentingan sosial dan lingkungan; adalah terwujudnya keinginan konsumen untuk memperoleh hasil yang optimal dari penggunaan sumber-sumber ekonomi mereka dalam mendapatkan barang dan jasa yang merupakan kebutuhan hidup, sehingga konsumen memerlukan informasi yang benar mengenai produk yang mereka konsumsi, sebab jika tidak maka akan terjadi gejolak sosial apabila konsumen mengkonsumsi produk yang tidak aman; Kepentingan ekonomi para pelaku usaha untuk mendapatkan laba yang sebesarbesarnya adalah sesuatu yang wajar, akan tetapi daya beli konsumen juga harus dipertimbangkan dalam artian pelaku usaha jangan memikirkan keuntungan semata tanpa memerinci biaya riil produksi atas suatu produk yang dihasilkan; Kepentingan perlindungan hukum konsumen adalah akses konsumen terhadap keadilan acces to justice), konsumen berhak untuk dilindungi dari perlakuan-perlakuan pelaku usaha yang merugikan.

Betapa pentingannya perlindungan konsumen maka Perserikatan Bangsa-Bangsa (PBB) mengeluarkan Resolusi dalam putusan Sidang Umum PBB pada sidang ke-106 tanggal 9 April 1985, menegaskan 6 enam) kepentingan konsumen, yaitu sebagai berikut: Pertama, perlindungan konsumen dari bahaya terhadap kesehatan dan keamanannya; Kedua, promosi dan perlindungan pada kepentingan ekonomi konsumen; Ketiga, tersedianya informasi yang mencukupi, sehingga memungkinkan dilakukannya pilihan sesuai kehendak; Keempat, pendidikan konsumen; Kelima, tersedianya cara-cara ganti rugi yang efektif; dan Keenam, kebebasan membentuk organisasi konsumen dan diberinya kesempatan kepada mereka untuk menyatakan pendapat sejak saat proses pengambilan keputusan yang berkaitan dengan kepentingan konsumen. ${ }^{10}$

Berdasarkan resolusi PBB tersebut maka kegiatan pemberdayaan konsumen perlu untuk dilakukan, sebagaimana terdapat pada poin ketiga yaitu pendidikan konsumen. Kegiatan pemberdayaan konsumen harus melibatkan banyak pihak agar pemberdayaan konsumen dapat terwujud. Pihak-pihak yang dapat terlibat antara lain pemerintah, pelaku usaha, konsumen, serta masyarakat.

Sementara itu The Economic Law and Improved Procurement System Project (ELIPS), mengemukakan sembilan materi rumusan hukum perlindungan konsumen, yaitu : pertama, ketidaksetaraan dalam kekuatan tawar-menawar; kedua, kebebasan berkontrak versus keadilan dalam kontrak; ketiga, persyaratan untuk memberikan informasi kepada konsumen, yang meliputi hukum pengumuman yang umum dan hukum pengumuman tentang keuangan; keempat, peraturan tentang

10 Az. Nasution, Sekilas Hukum Perlindungan Konsumen, Majalah Hukum dan Pembangunan, Tahun XVI No. 6 Desember, Jakarta: FH UI, 1986, hlm. 70 
perilaku/tindakan penjual, yang meliputi petunjuk/arahan yang salah dan kelicikan dalam perdagangan; kelima, peraturan tentang mutu produk, yang meliputi garansi dan keamanan produk; keenam, akses terhadap kredit pelaporan, kredit, nondiskriminasi); ketujuh, batasbatas hak mengakhiri masa jaminan; kedelapan, peraturan tentang harga; dan kesembilan, pembetulan.

Masyarakat Eropa Europese Ekonomische Gemeenschap atau EEG) juga telah menyepakati lima hak dasar konsumen sebagai berikut: ${ }^{11}$ Hak perlindungan kesehatan dan keamanan recht op bescherming van Zijn gezendheid en veiligheid); Hak perlindungan kepentingan ekonomi recht op bescherming van zijn economische belangen); Hak mendapat ganti rugi recht op schadevergoeding); Hak atas penerangan recht op voorlichting en vorming); Hak untuk didengar recht om te worden gehord).

Penyelenggaraan perlindungan konsumen di Indonesia diatur dalam Undang-Undang Nomor 8 Tahun 1999 Tentang Perlindungan Konsumen (UUPK). Pembentukan Produk hukum ini dipengaruhi banyak faktor, yaitu: faktor iklim politik yang semakin demokratis, faktor internal kepentingan konsumen Indonesia sendiri, dan faktor perkembangan sistem perdagangan global yang dikemas dalam kerangka World Trade Organization (WTO), maupun program International Monetary Fund (IMF), dan Program Word Bank. ${ }^{12}$

Pembentukan UUPK merupakan satu dari empat paket undangundang berdasarkan Letter Of Intent dengan International Monetary Fund, pengaruh globalisasi dan perdagangan bebas, untuk peningkatan harkat dan martabat konsumen serta penumbuhkembangan sikap pelaku usaha yang bertanggung jawab dari caveat emptor ke caveat venditor). ${ }^{13}$

Pentingnya keamanan pangan secara filosofis berkenaan dengan kebutuhan dasar manusia, serta kesejahteraan manusia yang dijamin dalam Undang-Undang Dasar Negara Republik Indonesia 1945 yaitu pada Pasal 28A "setiap orang berhak untuk hidup serta berhak mempertahankan hidup dan kehidupannya. Terkait dengan kebutuhan pangan termasuk pangan yang aman untuk dikonsumsi dapat dilihat pada Pasal 28C ayat 1) yang menyatakan bahwa setiap orang berhak mengembangkan diri melalui pemenuhan kebutuhan dasarnya, berhak mendapat pendidikan dan memperoleh manfaat dari ilmu pengetahuan dan teknologi, seni dan budaya, demi meningkatkan kualitas hidupnya dan demi kesejahteraan umat manusia. Frasa kebutuhan dasar dapat dimaknai adalah pangan yang mutlak diperlukan untuk

11 Ahmadi Miru \& Sutarman Yodo, Hukum Perlindungan Konsumen, Jakarta: PT.Raja Grafindo Persada, 2011, hlm. 39

12 Inosentius Samsul, Perlindungan Konsumen: Kemungkinan Penerapan Tanggung Jawab Mutlak, Jakarta: Program Pascasarjana Fakultas Hukum Universitas Indonesia, 2004, hlm. 127.

13 Yusuf Shofie, Sinopsis dan Komentar Undang-Undang Perlindungan Konsumen (Panduan Bagi Konsumen dan Pelaku Usaha), Jakarta: Perum Percetakan Negara Republik Indonesia, 2008, hlm, 5. 
mempertahankan hidup dan kehidupannya. Hak untuk hidup dan mempertahankan hidup dan kehidupannya sangat terkait dengan pangan sebagai salah satu kebutuhan dasar manusia seperti yang tertuang pada Pasal 28C ayat 1). Oleh karena itu, ketersediaan pangan bagi rakyat Indonesia menjadi kewajiban pemerintah untuk menyediakannya. Agar setiap orang yang mengonsumsi pangan tersebut dapat hidup dan mempertahankan kehidupannya, maka pangan atau bahan pangan tersebut juga harus aman, sehingga di sinilah keterkaitan Keamanan Pangan dengan Undang-Undang Dasar Negara Republik Indonesia 1945.

Kondisi keamanan pangan tergantung pada sistem pengawasan yang komprehensif, tidak hanya berdasarkan pengawasan terhadap industri pangan yang memproduksi pangan, tetapi juga pengawasan terhadap seluruh rantai pangan, misalnya pengawasan proses produksi pakan ternak. Dengan demikian, sistem pengawasan keamanan pangan yang efektif juga dapat dijadikan alat untuk:

1. Melindungi kesehatan masyarakat melalui penurunan risiko akan terjadinya keracunan pangan atau penyakit akibat pangan (foodborne diseases);

2. Melindungi masyarakat dari pangan yang tidak aman, tidak layak konsumsi, berlabel menyesatkan dan hasil penipuan (food fraud);

3. Berkontribusi dalam pengembangan ekonomi melalui kepercayaan konsumen terhadap sistem pengawasan keamanan pangan dan penyediaan dasar hukum perdagangan pangan, baik secara nasional maupun internasional". ${ }^{14}$

\section{Sistem Pengawasan Keamanan Produk Pangan berbasis Manajemen Risiko}

Seiring perkembangan jaman dan teknologi maka sistem pengawasan keamanan juga mengalami perkembangan, yaitu Program Manajemen Risiko (Risk Management Program) Pangan, pengawasan untuk menjamin keamanan dan mutu pangan melalui pengawasan berbasis risiko secara mandiri oleh industri pangan. Dalam pengawasan model ini pengawasan keamanan pangan mengarah pada kemandirian keamanan pangan, dimana pola pengawasan berbasis pemerintah diubah menjadi pola pengawasan berbasis kemandirian industri.

Program tertulis tersebut dirancang untuk memastikan pemenuhan persyaratan keamanan, mutu dan gizi pangan serta kepatuhan terhadap peraturan dan perundangan yang berlaku oleh industri pangan, serta didesain untuk mendorong industri pangan secara konsisten menerapkan sistem jaminan mutu dan keamanan pangan, dimana industri harus menjamin dan memastikan keamanan

14 Lampiran Peraturan Badan Pengawas Obat Dan Makanan Nomor 23 Tahun 2018 Tentang Pedoman Pengawasan Pangan Industri Rumah Tangga 
pangan pada produk yang diproduksi dan dijual ke pasar, sedangkan Badan Pengawas Obat dan Makanan bertugas mengawasi keamanan pangan yang beredar dengan menitik beratkan pada post market bukan pre market.

Pengawasan keamanan pangan berbasis risiko diarahkan dimulai dari perencanaan yang diarahkan berdasar pada aspek teknis, ekonomi, sosial dan spasial. Aspek-aspek tersebut dilakukan dengan pendekatan analisis risiko yaitu dengan memprioritaskan pengawasan kepada halhal yang berdampak risiko lebih besar agar pengawasan yang dilakukan lebih optimal. Selain itu, penguatan sistem pengawasan dimaksudkan untuk meningkatkan perlindungan kepada kelompok rentan meliputi balita, anak usia sekolah, dan penduduk miskin. Muara dari pengawasan keamanan pangan adalah untuk memberikan perlindungan kepada konsumen dari bahaya mengkonsumsi pangan yang tidak aman yang tercemar bahan kimia, biologis, bahan tambahan pangan.

Menurut Pasal 30 ayat 1 UUPK menyebutkan bahwa pengawasan terhadap penyelenggaraan perlindungan konsumen serta penerapan ketentuan peraturan perundang-undangan dilaksanakan oleh Pemerintah, Masyarakat, Lembaga Perlindungan Konsumen Swadaya Masyarakat

Pelaksanaan tugas pengawasan selain dibebankan kepada pemerintah, juga dilimpahkan kepada masyarakat, baik berupa kelompok, perorangan, maupun lembaga swadaya masyarakat. Masyarakat dapat melakukan penelitian, pengujian, dan/atau penyurveian terhadap barang-barang yang beredar di pasar. Aspek pengawasan yang dilakukan masyarakat ini meliputi : pemuatan informasi tentang resiko penggunaan barang jika diharuskan, pemasangan label, pengiklanan, dan lain-lain yang disyaratkan berdasarkan ketentuan peraturan perundang-undangan dan kebiasaan dalam praktik dunia usaha. ${ }^{15}$

Harus dibedakan tugas pengawasan yang dilakukan oleh masyarakat, lembaga swadaya masyarakat hanya dilakukan terhadap barang dan/atau jasa yang beredar di pasar, sedangkan terhadap sarana dan pra sarana produksi dan distribusi hanya dapat dilakukan oleh pemerintah. ${ }^{16} \mathrm{Hal}$ ini berarti bahwa pengawasan yang dilakukan masyarakat, Lembaga Perlindungan Konsumen Swadaya Masyarakat ruang lingkup terbatas jika dibandingkan dengan lingkup pengawasan yang menjadi kewenangan pemerintah.

Ketentuan tentang pengawasan perlindungan konsumen secara teknis diatur dalam Pasal 8 Peraturan Pemerintah Nomor 58 Tahun 2001 Tentang Tentang Pembinaan Dan Pengawasan Penyelenggaraan Perlindungan Konsumen, yang menyatakan: 
1) Pengawasan oleh pemerintah dilakukan terhadap pelaku usaha dalam memenuhi standar mutu produksi barang dan/atau jasa, pencantuman label dan klausula baku, serta pelayanan purna jual barang dan/atau jasa. 2) Pengawasan sebagaimana dimaksud dalam ayat 1) dilakukan dalam proses produksi, penawaran, promosi, pengiklanan, dan penjualan barang dan/atau jasa. 3) Hasil pengawasan sebagaimana dimaksud dalam ayat 2) dapat disebarluaskan kepada masyarakat.

Berdasarkan ketentuan di atas dapat dinyatakan bahwa aspek keamanan produk pangan yang diproduksi oleh Industri Rumah Tangga juga harus diawasai dengan tujuan agar produk pangan yang dihasilkan dan diperjualbelikan memenuhi standar keamanan pangan dan bermutu. Pengawasan ini merupakan langkah untuk melindungi konsumen dari ancaman produk pangan yang tidak aman. Pengawasan yang dilakukan oleh pemerintah terhadap industri rumah tangga merupakan pelaksanaan atas hak konsumen atas keamanan barang dan jasa sebagaimana dimaksud dalam Pasal 3 UUPK.

Ahmadi Miru dan Sutarman Yudo memberikan komentar atas Pasal 30 UUPK, dengan mengatakan:

"bahwa ketentuan ini cukup menjanjikan upaya perlindungan konsumen melalui pemberdayaan setiap unsur yang ada yaitu masyarakat, lembaga perlindungan konsumen swadaya masyarakat disamping pemerintah sendiri melalui menteri dan/atau menteri teknis yang terkait. Selanjutnya dikemukakan bahwa Pasal-pasal yang mengatur tentang tugas pembinaan dan pengawasan dari pemerintah , memperjelas kedudukan bidang hukum perlindungan konsumen sebagai salah satu bidang hukum yang berada dalam kajian hukum ekonomi. Sebagai bidang hukum ekonomi selain melibatkan berbagai disiplin ilmu, ciri utama lainnya berupa keterlibatan pemerintah dalam pengaturan ekonomi rakyat seperti hubungan antara pelaku usaha dengan konsumen, berdasarkan asas keseimbangan kepentingan, asas pengawasan publik, dan asas campur tangan negara terhadap kegiatan ekonomi, yang ketiganya bersumber dari aspek hukum publik. ${ }^{17}$

Adanya campur tangan pemerintah dalam kegiatan perekonomian sangat dipengaruhi oleh perkembangan teori negara hukum kesejahteraan (welfare state) yang mewajibkan negara atau pemerintah untuk melindungi, menjaga kepentingan umum atau masyarakat. Prinsip dasar negara kesejahteraan yaitu adanya keterlibatan negara bagi kesejahteraan masyarakat dianut oleh negara Indonesia yaitu melalui Pembukaan dan Pasal 33 UUD NRI.

Sistem perlindungan konsumen di Indonesia menurut Wahyu Sasongko melibatkan tiga pihak ialah konsumen, pelaku usaha, dan pemerintah. Hal ini dapat dipahami karena sebagaimana diatur dalam konstitusi Undang-Undang Dasar 1945 ditegaskan bahwa Negara

17 Ahmadi Miru dan Sutarman Yudo, Hukum Perlindungan Konsumen, Jakarta: RajaGrafindo, 2005, hlm. 184-185. 
Republik Indonesia didirikan bukan hanya untuk melindungi rakyatnya, tetapi harus dapat menciptakan negara kesejahteraan welfare state). Untuk itu, maka negara melalui pemerintah harus aktif memberikan pelayanan kepada masyarakat social service state) di berbagai bidang dan sektor, termasuk penyelenggaraan perlindungan konsumen sebab konsumen adalah rakyat Indonesia yang posisinya lemah di hadapan pelaku usaha sehingga kepentingan dan hak-hak konsumen dapat terlindungi. 18

Pelaksanaan atas penyelenggaraan perlindungan konsumen perlu diawasi dengan seksama, karena melalui pengawasan akan dapat diketahui adakah penyimpangan dalam pelaksanaan perlindungan konsumen atau pengawasan untuk melihat penerapan penegakan ketentuan UUPK apakah sudah berada dan berjalan pada jalur yang benar on the right track) sesuai dengan tujuan perlindungan konsumen atau tidak. Pengawasan secara sederhana dapat dirumuskan segala usaha atau kegiatan untuk mengetahui dan menilai kenyataan yang sebenarnya mengenai sasaran dan obyek yang diperiksa.

Secara umum pengawasan dapat dibedakan berdasarkan tahapan dan tujuannya: ${ }^{19}$

1. Pengawasan sebelum pelaksanaan atau masih dalam perencanaan, tujuannya untuk pencegahan (Preventif);

2. Pengawasan selama atau sedang proses berlangsung, tujuannya untuk perbaikan dan pemulihan (Kuratif);

3. Pengawasan setelah pekerjaan atau kegiatan selesai dilakukan atau dilaksanakan (post actum), tujuannya untuk penanggulangan dan pemberantasan (Represif).

Konsep pengawasan di atas jika dihubungankan dengan kegiatan pengawasan terhadap penyelenggaraan perlindungan konsumen dapat diuraikan sebagai berikut, sebelum pelaku usaha atau produsen memulai usaha produksinya maka terlebih dahulu harus memiliki izin usaha, pada tahap ini pemerintah sebagai lembaga yang berwenang mengeluarkan izin harus meneliti data-data dan informasi yang tepat dan benar bahwa usaha yang akan dijalankan merupakan usaha yang baik dan memenuhi syarat produksi yang sesuai peraturan perundangundangan yang berlaku. Pemerintah tidak boleh asal memberikan ijin usaha.

Selanjutnya pada tahap proses produksi oleh produsen atau pelaku usaha, pemerintah wajib melakukan pengawasan dengan cara mendatangi lokasi tempat dimana proses produksi berlangsung. Dengan cara ini akan dapat diketahui tingkat keamanan produksi pangan yang dihasilkan oleh produsen. Sedangkan pengawasan yang setelah proses produksi dilakukan dengan cara meneliti produk pangan yang beredar di

18 Wahyu Sasongko, Ketentuan-Ketentuan Pokok Hukum Perlindungan Konsumen, Bandar Lampung: Penerbit Unila, 2007, hlm. 117

19 Ibid, hlm. 120 
pasar yang dapat dilakukan dengan uji laboratorium, uji sampling, dengan tujuan untuk mengetahui tingkat keamanan produk pangan.

Dalam praktik pengawasan yang dilakukan oleh Badan Pengawas Obat dan Makanan RI dikenal istilah pre-market dan post market. Pre Market adalah pengawasan yang dilakukan serta penilaian dan pengujian atas mutu keamanan sebelum kosmetik diedarkan. Post Market adalah pengawasan yang dilakukan setelah produk diedarkan di masyarakat, antara lain inspeksi sarana produksi dan distribusi, monitoring efek samping, sampling dan uji laboratorium, penilaian dan pengawasan iklan atau promosi, serta penyebaran informasi melalui edukasi masyarakat dan public warning.

Peraturan perundangan-undangan yang secara khusus mengatur tentang pangan adalah Undang-Undang No. 18 Tahun 2012 tentang Pangan UU Pangan). Dalam UUP pengaturan tentang pangan meliputi tujuan penyelenggaraan keamanan pangan, tanggung jawab setiap orang yang terlibat dalam rantai pangan, standar mutu, hingga sanksi bagi yang melalaikan penyelenggaraan keamanan pangan.

Pangan adalah segala sesuatu yang berasal dari sumber hayati produk pertanian, perkebunan, kehutanan, perikanan, peternakan, perairan, dan air, baik yang diolah maupun tidak diolah yang diperuntukkan sebagai makanan atau minuman bagi konsumsi manusia, termasuk bahan tambahan Pangan, bahan baku Pangan, dan bahan lainnya yang digunakan dalam proses penyiapan, pengolahan, dan/atau pembuatan makanan atau minuman. Sedangkan pengertian Keamanan Pangan adalah kondisi dan upaya yang diperlukan untuk mencegah Pangan dari kemungkinan cemaran biologis, kimia, dan benda lain yang dapat mengganggu, merugikan, dan membahayakan kesehatan manusia serta tidak bertentangan dengan agama, keyakinan, dan budaya masyarakat sehingga aman untuk dikonsumsi.

Terkait dengan keamanan pangan pada Pasal 67 UU Pangan dinyatakan: Keamanan Pangan diselenggarakan untuk menjaga Pangan tetap aman, higienis, bermutu, bergizi, dan tidak bertentangan dengan agama, keyakinan, dan budaya masyarakat. Keamanan Pangan dimaksudkan untuk mencegah kemungkinan cemaran biologis, kimia, dan benda lain yang dapat mengganggu, merugikan, dan membahayakan kesehatan manusia. Sedangkan terkait dengan jaminan keamanan pangan di atur pada Pasal 68, Pemerintah dan Pemerintah Daerah menjamin terwujudnya penyelenggaraan Keamanan Pangan di setiap rantai Pangan secara terpadu. Pemerintah menetapkan norma, standar, prosedur, dan kriteria Keamanan Pangan. Petani, Nelayan, Pembudi Daya Ikan, dan Pelaku Usaha Pangan wajib menerapkan norma, standar, prosedur, dan kriteria Keamanan Pangan. Pemerintah dan/atau Pemerintah Daerah wajib membina dan mengawasi pelaksanaan penerapan norma, standar, prosedur, dan kriteria Keamanan Pangan. 
Fardiaz mengemukakan ada empat masalah utama mutu dan keamanan pangan nasional yang berpengaruh terhadap perdagangan pangan baik domestik maupun global yaitu: Pertama, produk pangan yang tidak memenuhi persyaratan mutu keamanan pangan, yaitu: 1) Penggunaan bahan tambahan pangan yang dilarang atau melebihi batas dalam produk pangan; 2) Ditemukan cemaran kimia berbahaya pestisida, logam berat, obat-obat pertanian) pada berbagai produk pangan; 3) Cemaran mikroba yang tinggi dan cemaran microba patogen pada berbagai produk pangan; 4) Pelabelan dan periklanan produk pangan yang tidak memenuhi syarat; 5) Masih beredarnya produk pangan kadaluwarsa, termasuk produk impor; 6) Pemalsuan produk pangan; 7) Cara peredaran dan distribusi produk pangan yang tidak memenuhi syarat; dan 8) Mutu dan keamanan produk pangan belum dapat bersaing di pasar Internasional. Kedua, masih banyak terjadi kasus kercunan makanan yang sebagian besar belum dilaporkan dan belum diidentifikasi penyebabnya. Ketiga, masih rendahnya pengetahuan, keterampilan, dan tanggung jawab produsen pangan produsen bahan baku, pengolah dan distributor) tentang mutu dan keamanan pangan, yang ditandai dengan ditemukannya sarana produk dan distribusi pangan yang tidak memenuhi persyaratan GAP, GHP, GMP, GDP, dan GRP), terutama pada industri kecil/rumah tangga. Dan keempat, rendahnya kepedulian konsumen tentang mutu dan keamanan pangan yang disebabkan pengetahuan yang terbatas dan kemampuan daya beli yang rendah, sehingga mereka masih membeli produk pangan dengan tingkat mutu dan keamanan yang rendah. 20

\section{Penutup}

Besarnya manfaat pengawasan keamanan produk bagi kepentingan konsumen maka diperlukan perubahan paradigam pengawasan dari yang bersifat konvensional menjadi pengawasan modern yang berbentuk sistem manajemen risiko. Pengawasan berbasis manajemen risiko merupakan bagian dari pelaksanaan tugas pengawasan penyelenggaraan perlindungan konsumen sebagaimana diamanahkan dalam Undang-Undang No. 8 Tahun 1999 Tentang Perlindungan Konsumen, dan Undang-Undang No. 18 Tahun 2012 Tentang Pangan.

\section{DAFTAR PUSTAKA}

Badan Pengawasan Obat dan Makanan RI, Laporan Kinerja 2016, Direktorat Pengawasan Produk dan Bahan Berbahaya, diakses

20 Budi Cahyon, Food Safety dan Implementasi Quality System Industri Pangan di Era Pasar Bebas, www.bappenas.go.id., diakses tanggal 23 Mei 2017 
tanggal 2 Januari dari 2019 ,

https://www.pom.go.id/new/admin/dat/20180710/22.\%20Lapki

n\%20Dit\%20Was\%20PBB\%20Tahun\%202016.pdf

Badan Pengawasan Obat dan Makanan RI, 2015, "Hasil Uji Laboratorium", Laporan Tahun 2015.

Budi Cahyon, Food Safety dan Implementasi Quality System Industri Pangan di Era Pasar Bebas, www.bappenas.go.id., diakses tanggal 23 Mei 2017.

Kompas.com, "Teliti 7 Hal Ini Saat Baca Label Makanan”, diakses tanggal 16 maret 2017 dari ", https://lifestyle.kompas.com/read/2012/07/17/0718222/Teliti $\%$ 20Ini.Saat.Baca.Label.Makanan

L. Tanya, Bernald, Yoan N. Simanjuntak, Markus Y.Hage, 2010, Teori Hukum Strategi Tertib Hukum Manusia Lintas Ruang dan Generasi, Yogyakarta : Genta Publishing.

Mansyur, M Ali, 2007, Penegakan Hukum Tentang Tanggung Gugat Produsen Dalam Perwujudan Perlindungan Konsumen, Yogyakarta: Penerbit GentaPress.

Miru, Ahmadi \& Sutarman Yodo, 2001, Hukum Perlindungan Konsumen, Jakarta: PT.Raja Grafindo Persada.

Nasution, Az, 1986, Sekilas Hukum Perlindungan Konsumen, Majalah Hukum dan Pembangunan, Tahun XVI No. 6 Desember, Jakarta: FH UI.

Samsul, Inosentius, 2004, Perlindungan Konsumen: Kemungkinan Penerapan Tanggung Jawab Mutlak, Jakarta: Program Pascasarjana Fakultas Hukum Universitas Indonesia.

Sasongko, Wahyu, 2007, Ketentuan-Ketentuan Pokok Hukum Perlindungan Konsumen, Bandar Lampung: Penerbit Unila.

Setiawan, 2001, Makalah Produsen atau Konsumen; Siapa Dilindungi Hukum, Jakarta.

Shofie, Yusuf, 2008, Sinopsis dan Komentar Undang-Undang Perlindungan Konsumen (Panduan Bagi Konsumen dan Pelaku Usaha), Jakarta: Perum Percetakan Negara Republik Indonesia.

Sidabalok, Janus, 2006, Hukum Perlindungan Konsumen di Indonesia, Bandung: PT. Citra Aditya Bakti. 
Undang-Undang No. 8 Tahun 1999 Tentang Perlindungan Konsumen, Undang-Undang No. 18 Tahun 2012 Tentang Pangan. 